\title{
TOLERANTNI DIJALOG IZMEĐU KRŠĆANSKE I MUSLIMASKE VJERE
}

Mato Zovkić

\author{
Univerzitet u Sarajevu \\ Katolički bogoslovni fakultet \\ mato.zovkic@bih.net.ba
}

UDK: 28:27]2-67

27:28]2-675

Pregledni rad

Primljeno 06/2018.

\section{Sažetak}

Na poziv dr. Nedžada Grabusa, muftije u Sloveniji, da se jednom temom uključi u znanstvenu konferenciju u prigodi stote obljetnice prve džamije u Sloveniji, autor je na temelju svojeg iskustva pripadnika kršćanske manjine u gradu s većinskim muslimanskim stanovništvom te na osnovi smjernica Drugoga vatikanskog sabora o dijalogu s muslimanima obradio potrebu razumskog branjena vlastite vjere bez vrijeđanja onih koji drugačije vjeruju. Potrebu razumske obrane kršćanstva izvodi iz 1 Pt 3,15-16 te Rim 12,1. Zatim ističe kako je nakon Drugoga vatikanskog apologetika postala fundamentalna teologija. U islamu se potreba razumskog pristajanja uz objavu izvodi iz K 96, 1-5; 17,73-75 8,2; 13,28 i dr. Polemika s muslimanima počela je s Ivanom Damaščaninom, prenesena djelcem Tome Akvinskog „Traktat o razlozima vjere protiv Saracena“ $i$ trajala je do sredine 20. st. Promjenu su unijeli kršćanski znanstvenici koji su živjeli među muslimanima, proučavali arapski jezik $i$ kulturu muslimana te protumačili islamski monoteizam drugim kršćanima. Plodovi njihova zalaganja ušli su u saborske dokumente DH, NAE, GS. Muslimanski teolozi već od 9. st. turde da kršćani iskrivljuju evanđelje što ga je Isus primio od Boga, da je uvreda jedincatom Bogu kultno štovanje Trojstva. Zajedan od primjera dijaloškog stava muslimana autor uzima prijevod i komentar „The Study Quran“ (New York 2015.), koji su pod vodstvom profesora Nasra priredili muslimanski znanstvenici $u$ Americi, a od bošnjačkih teologa navodi radove S. Balića, $R$. Hafizovića, E. Karića, F. Karčića i A. Silajdžića. Smatra da imami i svećenici u tjednim molitvenim susretima mogu vlastite vjernike dublje uvoditi u razumijevanje vjere, bez izrugivanja onih koji imaju pravo ostati drugačiji. To mogu i vjeroučitelji u konfesionalnom vjeronauku u javnim školama. Za razumsku obranu vlastite vjere potrebno je učiti u 
odrasloj dobi vjeru zajednice kojoj pripadamo te se iskreno informirati o vjeri sugovornika s kojima imamo neke zajedničke vrijednosti, ali dogmatske razlike ostaju.

Ključne riječi: muslimani, kršćani, razumski dokazi, poštovanje, dijalog.

\section{UVOD}

Prema popisu stanovništva iz 2002. godine u Sloveniji ima 48.266 Muslimana, što je 2,4 \% stanovništva. Muftija dr. Nedžad Grabus istaknuo je da je prva džamija u Sloveniji bila podignuta za bošnjačke muslimanske vojnike u sastavu austrougarske vojske 2017. godine: „Džamija u Logu pod Mangartom, čije su dimenzije najvjerojatnije bile $7 \times 7$ metara, a visina munare oko 12 metara, ima simboličku važnost za islamsku zajednicu. Činjenica da je 1917. godine pisano o džamiji i reisu-1-ulemi je dokaz o značajnom jubileju IZ. Zato IZ u Sloveniji 2017. označava kao jubilarnu i svečanu godinu."1 Bosna i Slovenija spadale su tada u istu državu, AustroUgarsku Monarhiju. Istina, Monarhija se ubrzo raspala i Slovenija se uključila u novu državu Južnih Slavena, ali je iz tog vremena ostalo da Republika Slovenija danas priznaje muslimane kao jednu od priznatih vjerskih zajednica na temelju zakona iz godine 2012 . Kršćanstvo i islam su monoteističke religije koje se temelje na Božjoj objavi i ljudskom razumskom razmišljanju. ${ }^{2}$ Djelujući kao katolički teolog u Sarajevu, koje je sada grad s apsolutnom većinom muslimana, u Bosni i Hercegovini kao zemlji s polovicom muslimanske populacije, svim srcem i pameću podupirem dijalog s muslimanima u duhu Drugoga vatikanskog sabora. U tom duhu nastojim kod svojih sunarodnjaka i katolika otkloniti islamofobiju, uvjeren da kršćani i muslimani mogu pridonositi miru, pravdi i medusobnom razumijevanju u pluralnom društvu i sekularnoj državi.

Ovim prilogom želim pokazati da je moguće vlastitu vjeru razumski obrazlagati, bez polemičkog karikiranja vjere drugih. Vjerski poglavari, svećenici i imami koji predvode tjedno bogoslužje po župama i džematima te vjeroučitelji konfesionalnog vjeronauka $u$ državnim školama (što je uvedeno u $\mathrm{BiH}$ od 1993.) mogu odgajati

1 Nedžad Grabus, Otkrivanje zaboravljene muslimanske i bošnjačke prisutnosti u Sloveniji, Preporod 1, svibanj 2017., 23.

2 Usp. Giuseppe Rizzardi, Islam tra autocosienza islamica ed islamologia cristiana, u: Mariano Crociata (ed.), Teologia delle religioni - la questione del metodo, Roma, 2006., 167-201; Marcello Di Tora, Teologia delle religioni e islamologia. Osservazioni sulla relazione di Giuseppe Rizzardi, u: Mariano Crociata (ed.), Teologia delle religioni - la questione del metodo, Roma, 2006., 203-211. 
vlastite vjernike za miran život i građansku solidarnost. Oni ne bi trebali sami pisati pamflete protiv „drugih“ niti prevoditi polemičke brošure i knjige, premda ne mogu spriječiti neke članove svojih zajednica da to čine privatno. ${ }^{3}$

\section{KADA ODRASLI DOSTATNO UPOZNAJU VJERU U BOGA OBJAVE, MOGU JE RAZUMSKI OBRAZLAGATI}

Kršćani vjeruju u Boga koji se objavio po Isusovim djelima i riječima, a to je zapisano u 27 spisa koji su izvorno pisani na grčkom između godine 50. i godine 120. Srž Novoga zavjeta su četiri kanonska evanđelja (Matej, Marko, Luka i Ivan), koja pokazuju tri faze nastajanja:

- Povijesni Isus pozivao je na obraćenje radi podlaganja Božjoj vladavini te u znak uvjerenja da ga Bog za to ovlašćuje ozdravio neke bolesnike i činio druga čudesa.

- Isusovi povijesni svjedoci, dvanaestorica apostola i njihovi suradnici, propovijedali su Židovima Palestine i ljudima grčke kulture u Rimskom Carstvu Isusovo učenje i djelovanje.

- Evanđelisti su iz propovijedane građe o Isusu sastavili svaki svoje evanđelje, vodeći računa o duhovnom stanju i potrebama vjernika u vlastitoj povijesnoj zajednici.

Isus je Židov iz prvoga stoljeća koji se osjećao od Boga poslanim da pročisti i reformira vjeru svojeg naroda. On je Božju dobrotu i milosrđe činio dostupnima i strancima, poganima svojeg vremena. Tražio je da njegovi suradnici o tome svjedoče svojim propovijedanjem i ponašanjem. Uključivanje u Isusov pokret pretpostavlja vjeru u Boga objave. U Isusovo vrijeme nije bilo teoretskog ateizma, ali su ljudi kao članovi obiteljske i nacionalne zajednice većinom bili politeisti i od njih se očekivalo da na državnim svetkovinama sudjeluju u javnom bogoštovlju te poglavaru države iskazuju religiozno štovanje kao božanstvu. Židovi su imali povlasticu da u

3 Ovdje mislim na knjigu prevedenu $\mathrm{s}$ francuskog kojom je izrugana Biblija, a autor je nekadašnji katolik koji je prešao na islam, Maurice Bucaille, Biblija, Kur'an i nauka II. izdanje, El-kalem, Sarajevo, 2007. El-kalem je izdavačka kuća Islamske zajednice u Sarajevu. Od 1993. do 2010. godine prevedeno je i tiskano u BiH petnaestak brošura i knjiga u kojima se borbeni arapski ili južnoafrički muslimanski autori izruguju kršćanstvu, ali to su privatni prevoditelji i izdavači za koje ne odgovara vodstvo Islamske zajednice u BiH. Usp. Mato Zovkić, Kako svojima govoriti o svetoj knjizi drugih bez karikiranja?, Vrhbosnensia, 9 (2005.) 1, 15-128; Isti: Dialogische und polemische Wahrenhmungen des Christentums durch Muslime in Bosnien-Herzegowina, Vrhbosnensia, 14 (2010.) 1, 159-171. 
svojim sinagogama ne moraju držati kip cara, ali su trebali upućivati Bogu zajedničku molitvu za poglavara države i prosperitet zemlje. U takvom povijesno-kulturnom ozračju iz Isusova pokreta obnove razvilo se kršćanstvo kao nova monoteistička religija koja je, po uzoru na Isusa, predlagala ljudima da caru daju što je njegovo, a Bogu što je njegovo, kako je Isus odgovorio na pitanje smiju li monoteistički vjernici plaćati državi porez kovanim novcem koji nosi lik vladara (usp. Mk 12,13-17).

Novozavjetni spisi nazivaju evanđeljem ili radosnom viješću koja se tiče dobra svih ljudi propovijedanje glavnih događaja života Isusa Krista, uključivši nasilnu smrt na križu i njegovo uskrsnuće, potvrđeno ukazanjima povijesnim svjedocima. To se osobito vidi iz nastupa jeruzalemskih propovjednika u Antiohiji Sirijskoj kao gradu u kojem su većinu činili pripadnici grčko-rimske kulture: „Neki su od njih bili Ciprani i Cirenci. Kad stigoše u Antiohiju, propovijedahu i Grcima navješćujući evanđelje: Gospodina Isusa“ (Dj 11,20). U poglavlju Djela apostolskih prije ovoga prizora Petar je svečano primio u zajednicu Isusovih sljedbenika rimskog časnika Kornelija na službi u Cezareji Primorskoj, nazvavši Isusovo djelovanje evanđeljem (Dj 10,34-41). Prema tradiciji rane Crkve Petar je tražio od rimskih državljana koji su kao neznatna manjina prihvatili vjeru u Boga očitovanog po Isusu da svoju vjeru opravdavaju pred drugim sugrađanima: „Budite uvijek spremni na odgovor svakomu koji od vas zatraži obrazloženje nade koja je u vama, ali blago i s poštovanjem“ (1Pt 3,15-16). Ovaj tekst odražava praksu da su odrasli kandidati za uključenje u kršćanstvo po krštenju i javnom prihvaćanju vjere bivali poučavani u kršćanskoj vjeri. Od njih se očekivalo da nakon slobodnog priključenja Crkvi svoju vjeru sve više upoznaju, po njoj žive i budu spremni na razumsko opravdanje onoga što prihvaćaju. Pavao je bio Židov iz dijaspore koji je studij židovske teologije završio u Jeruzalemu te je nakon obraćenja postao gorljivi propovjednik evanđelja među poganima. On od odraslih krštenika traži da njihovo služenje Bogu bude latreía logikē - razumno bogosluženje (Rim 12,1). Ti novozavjetni tekstovi bili su stoljećima kršćanskom učiteljstvu i teolozima nadahnuće za razumsko opravdanje vlastite vjere. Istina, u razdobljima međuetničke i međuvjerske hostilnosti to opravdanje često je prelazilo u podcjenjivanje i izrugivanje drugačijih. Tako su već u nekim spisima Novoga zavjeta Židovi prikazani kao od Boga odbačeni zato što su preko svojih vjerskih poglavara Isusa izručili na pogubljenje rimskoj vlasti. Iako je povijesni Isus Želio pročistiti vjeru Židova, a ne osnovati novu monoteističku religiju, s vremenom je nastao raskid između kršćanstva i židovstva na pitanju vjere $u$ Isusov transcendentalni identitet: za većinu Židova 
Isus je ostao običan Galilejac iz prvoga stoljeća, a za njegove povijesne svjedoke na čelu s Petrom on je Božji pomazanik i obećani Mesija, jedinstveni Sluga Božji, ali i Gospodin u posebnom smislu riječi.

Na crti obrambene apologetike protiv židovstva je djelo filozofa i mučenika Justina (100. - 165.) Dijalog s Trifonom, a obranu kršćanstva pred obrazovanim poganima napisao je koncem drugoga stoljeća pisac Poslanice Diognetu. ${ }^{4}$ Na Drugom vatikanskom saboru (1962. - 1965.) katoličko crkveno učiteljstvo donijelo je četiri dokumenta važna za odnos prema drugačijima u pluralnom svijetu: Dekret o ekumenizmu, Deklaraciju o odnosu Crkve prema nekršćanskim religijama, Deklaraciju o slobodi religije i Pastoralnu konstituciju o Crkvi u suvremenom svijetu. Od tada je nastala potreba da se dotadašnja apologetika kao obrana katoličke vjere uz napadanje drugačijih preobrazi u fundamentalnu teologiju kao racionalno opravdanje vlastite vjere uz poštivanje vjere drugačijih u pluralnom svijetu. ${ }^{5}$ Američki katolički teolog Richard R. Gaillardetz, profesor na University of Toledo u državi Ohio, ističe da bi nova apologetika ili fundamentalna teologija trebala njegovati pet važnih vrlina:

1. Izlagati pozitivno i učvršćivati radost vlastitog vjerovanja

2. Razvijati dijalog s onima koji drugačije vjeruju

3. Biti ekumenski otvorena prema drugim kršćanima

4. Biti svjesna povijesnih promašaja i nepravdi

5. Biti kulturno angažirana. ${ }^{6}$

Katolički proučavatelji fundamentalne teologije, zajedno sa zastupnicima ostalih teoloških grana, uvjereni su da teolozi trebaju biti intelektualni služitelji zajednice i zato otvoreni za konkretnu situaciju vjernika u pluralnim društvima, ne kabinetski znanstvenici koji su zatvoreni u svoj svijet.

U islamu kao monoteističkoj religiji bitan je Muhamedov doživljaj vlastitog poziva na vjeru i proročko poslanje među Arapima sedmoga stoljeća. Iz knjige Život Muhameda, a. s. M. H. Hejkala razvidno da je ovaj trgovac iz Meke u dobi od 40 godina bio razočaran što njegovi sunarodnjaci iskazuju religiozno štovanje nijemim idolima, da rješenje nije našao u susretima sa Židovima i kršćani-

4 Usp. Juraj Pavić - Tomislav Zdenko Tenšek, Patrologija, Zagreb, 1993., 68-71; 80-81.

5 Usp. Heinrich Fries, Von der Apologetik zu Fundamentaltheologie, Concilium, 6 (1969.) 6-7, 442-447; Avery Dulles, Church and Society, New York, 2008., 430442.

6 Richard R. Gaillardetz, Do we need a new(er) Apologetics, America Magazine, (2004.) 2, 26-33. Usp. Salvator Pié-Ninot, El doble origen y mètodo de la teología fundamental, Gregorianum, 98 (2018.) 2, 337-348. 
ma svoga vremena te da je šest mjeseci razmišljao u pećini Hira kod Meke. Ondje je doživio objavu Boga po anđelu Gabrijelu te se na početku uplašio da ga je opsjeo nečisti duh. Prva mu je povjerovala njegova žena Hatidža i najavila da će biti poslanik Božji u svome narodu. ${ }^{7}$ Muslimanski teolozi slažu se da je srž tog doživljaja zabilježena u suri 96,1-5, a zbio se u srpnju ili kolovozu godine 610 . Anđeo mu je govorio:

Čitaj, u ime tvoga Gospodara, Koji stvara,

Stvara čovjeka od zametka!

Čitaj, plemenit je Gospodar tvoj,

Koji përu podučava,

Koji čovjeka podučava onomu što ne zna

(prijevod Enesa Karića, 1993.).

Muhammed Asad u komentaru Kur'ana na engleskom koji je preveden i na bosanski ističe da je Prorok islama tada $u$ izvanrednom nadahnuću shvatio kako je pozvan „čitati“, to jest primati i shvaćati Božju poruku čovjeku. Čitati u ovom doživljaju znači svjesno primati - uz glasno recitiranje ili bez njega - riječi i misli primljene iz vanjskog izvora, iz poruke Kur'ana. „Përo“ je metafora za znanje zabilježeno pisanjem. Bog poučava znanju koje ljudi ne mogu znati sami po sebi: „Poučavanje čovjeka znači čin Njegova objavljivanja, preko vjerovjesnikâ, duhovnih istina i moralnih standarda koji ne mogu biti jednoglasno ustanovljeni samo preko ljudskog iskustva i razmišljanja; na taj način se opisuje fenomen Božje objave kao takve."8

Muhamed je bio uvjeren da ga Bog vodi $u$ ispravnom razumijevanju i tumačenju primljene objave. Tako Bog poručuje Proroku:

I umalo da te oni odvrate od onoga

što ti objavljujemo Mi,

7 Usp. poglavlje „Od braka do poslanstva“, u: Muhammed Husejn Hejkal, Život Muhameda, a. s., Sarajevo, 2004., 144-156.

8 Muhammed Asad, Poruka Kur'ana. Prijevod i komentar, Sarajevo, 2004., 988. Ovaj uvaženi muslimanski teolog Europljanin rođen je godine 1900. u obitelji austrijskih Židova kao Leopold Weiss. U kući je govorio njemački i poljski, kao srednjoškolac naučio hebrejski, aramejski, engleski i francuski. U vrijeme nastajanja Palestine kao britanskog protektorata nakon Prvoga svjetskog rata pisao je kao novinar o problemima palestinskih muslimana. Godine 1926. prihvatio je islam kao osobnu vjeru te se s vremenom razvio u islamskog intelektualca. God. 1947. primio je državljanstvo Pakistana, djelovao u različitim ministarstvima te neko vrijeme bio delegat Pakistana u UN-u. Držao je da je islam kodeks života najbliži ljudskoj naravi i zato je do smrti godine 1992. ostao uvjereni musliman i praktični vjernik. 
da bi protiv Nas nešto drugo iznio ti,

i tad bi te za prijatelja uzeli!

A da te čvrstim nismo učinili,

gotovo da bi im se malo priklonio ti,

i tad bismo ti dali da dvostruku patnju u životu iskusiš

i dvostruku patnju nakon smrti!

Potom nikoga ne bi našao ko bi ti protiv Nas pomogao (17, 73-75).

Ovi ajeti stoje u suri 17, koja u arapskom nosi naslov El-Isrā, Noćno putovanje. Komentatori drže da je objavljena u godini prije hidžre te da sadrži prikaz Muhamedova noćnog putovanja u Jeruzalem gdje se događala ranija objava: „Ovo je jedna od mekanskih sura, koje svoju pažnju upućuju uglavnom na principe vjere, ovdje vjerska učenja o jedinstvenosti Allahovoj i danu proživljavanja. Međutim, njezin najistaknutiji dio posvećen je osobi Poslanika, a. s., čudima i neoborivim dokazima koji ukazuju na njegovu istinitost."9 Povijesno bi se ovdje radilo o pokušaju skupine iz plemena Kurejšija koji su nagovarali Proroka da prihvati njihove idole uz obećanje da bi oni njega prihvatili za proroka. Bog ga je svojom milošću učinio otpornim, a Prorok je uvjeren da bi grešnim ustupcima navukao na sebe sramotu i kaznu već u zemaljskom životu, dok ga lažni prijatelji ne bi mogli zaštititi od Božje kazne $u$ eshatonskoj fazi življenja.

Kur'ansko poimanje vjere vezano je uz arapske izraze imran i islam:

Vjernici su oni kojih srca strepe

kada se Allah spomene!

A kad im se uče ajeti Njegovi, vjerovanje im se poveća;

Takvi se oslanjaju na svoga Gospodara $(8,2)$.

Vjera znači priznavanje Božje jednote te konkretni odgovor podlaganja. Imenica iman izvedena je iz glagolskog korijena amana i znači činjenje sigurnim i polaganje povjerenja u nešto ili nekoga. Vjernik, mu' min (suprotno od kafir, nevjernik), je onaj koji razumije i prihvaća sadržaj Božje objave i time je ušao u stanje sigurnosti i povjerenja u Boga. Oni koji tako vjeruju imaju smirena srca spominjući Boga $(13,28) .{ }^{10}$ Bošnjački znanstvenik dr. Smail Balić (1920. - 2002.) djelovao je nakon Drugoga svjetskog rata u Austriji

9 Ramo Atajić (prev.), Prijevod Kur'ana sa tefsirom i komentarom na bosanskom jeziku, Knjiga 5, München, 2001., 1102-1103.

10 Usp. Jane J. Smith, Faith, u: Encyclopedia of the Qur'an, Volume Two E-I, Leiden, 2002., 162-172. 
i svojim spisima tumačio islam Europljanima kao miroljubivu religiju, osjećajući se muslimanom sposobnim za konstruktivan život u sekularnoj državi. On je u Leksikonu temeljnih religijskih pojmova na zamolbu urednika napisao većinu priloga o islamu. On razlaže da riječ „islam“ znači predanost u Bogu, ali i mir i spas u Njemu. Odbacuje uobičajeni naziv na njemačkom „muhamedanstvo, muhamedanci“ zato što se muslimani ne mole Muhamedu. Prema njemu „iman je samo jedan dio islama, i to najvažniji. Islam se u svojoj cjelovitosti sastoji od tri dijela: a) vjeroispovijesti, b) ispunjavanja religioznih dužnosti, c) poštovanja i izvršavanja islamskoga ćudorednoga kodeksa“. ${ }^{11}$ Vjeroispovijest obuhvaća šest stavaka:

1. Vjeru u jednoga Boga

2. Vjeru $u$ anđele

3. Vjeru u objavu ili u sveta pisma

4. Vjeru u Muhameda kao Božjeg poslanika

5. Vjeru u uskrsnuće nakon smrti i u sudnji dan

6. Vjeru u božansku predodređenost.

Ćudoredni kodeks oslanja se na iman ili vjeru te na islam ili društveno ozbiljenje islamskog životnog poretka. Abraham kao poslušni primatelj i vršitelj Božje objave prvi je musliman (Kur'an, 3,67-68). Vjera je Božja milost, ali pretpostavlja slobodno i razumsko prihvaćanje. Mnogobošci odbijaju odbaciti svoje idole:

A poslanici njihovi bi im odgovarali:

„Mi smo ljudi kao i vi,

ali Allah poslanstvo svoje dariva kome hoće

od Svojih robova,

mi vam možemo donijeti dokaz jasni

samo s dopuštenjem Allahovim,

pa, na Allaha nek se oslanjaju vjernici!“ $(14,11)$.

Ovaj ajet je dio odlomka koji ukazuje na temeljnu identičnost poruke koju su prenosili svi poslanici. Sadržaju božanske poruke trebaju se okrenuti svi koji traže istinu $(7,75 ; 13,43)$. „Kur’an se na mnogim mjestima (npr. 6,109-111 ili 13,31) zadržava na ništavosti - kako moralnoj, tako i intelektualnoj - zahtjeva da Božansko porijeklo poslaničke poruke bude dokazano dodirljivim, vanjskim sredstvima: jer moralno valjano i intelektualno opravdano uvjerenje o unutarnjoj istinitosti takve poruke može se dobiti samo preko

11 Smail Balić, Vjera - islamska, u: Leksikon temeljnih religijskih pojmova: Židovstvo, Kršćanstvo, Islam, (prijevod njemačkog izdanja iz godine 1996.), Zagreb, 2005., 515-516. 
‘svjesnog uvida dostupnog razumu’ $(12,108)$." 12 Ovdje je jasno da iman pretpostavlja razumsko usvajanje Božje poruke po poslaniku Muhamedu: „Vjera nije toliko uvjerenje u nešto ili prihvaćanje nečega što se ne vidi ili što nije očito izraženo osjetilima i razumu, koliko je svjedočenje za ono što netko smatra bezuvjetno istinitim. Što je, međutim, sadržaj vjere? Bit imana je ono što je mješavina mentalnog razabiranja, usmenog izgovaranja i vršenja dobrih djela."13 Vjera kod muslimana bitno povlači svjedočko djelovanje, djela u skladu s vjerom. Sačuvan je i često tumačen Poslanikov hadis o imanu i islamu: iman je vjera u Allaha, meleke, u Božju knjigu, poslanike i proživljavanje na Sudnji dan. Islam je nepridruživanje Bogu nikoga u njegovoj božanstvenosti, obavljanje propisanih namaza, izdvajanje od materijalnih dobara za socijalno pomaganje (zekat) te post u mjesecu objave ramadanu. ${ }^{14}$ Ebu Džafer Muhamed el-Taberi (839. - 923.) u svojem komentaru Kur'ana (Tafsir IX, 518) ističe da islam na jednoj razini označuje riječima izraženo podlaganje kojim netko ulazi u zajednicu muslimana, a na drugoj on je sukladan s imanom, koji uključuje totalno izručenje srca, uma i tijela. ${ }^{15}$

Iz ovog kratkog pregleda razvidno je da su kršćanstvo i islam religije objave koje traže pristanak srca i uma uz Božju objavu dostupnu po prorocima te da se mogu razumski obrazlagati i braniti.

\section{U VREMENU DIJALOGA PROUČAVAMO ZAJEDNIČKE} VRIJEDNOSTI, A RAZLIKE UVAŽAVAMO BEZ IZRUGIVANJA

Prisjetimo se da je godine 630. Muhamed sa svojim sljedbenicima mudro osvojio Meku i pretvorio je u buduće središte islama kao svjetske religije. Nakon Poslanikove smrti godine 632. za prvog kalifa i političkog vođu muslimana izabran je Ebu Bekr, koji je u dvije godine svoje vladavine učvrstio i proširio islamsku državu. Već 30. lipnja 634. Muslimani su pobijedili bizantsku vojsku kod Adžnadejna, a u deset godina vladavine kalifa Omera nastavljena je ekspanzija islama kao države i religije u svim pravcima. Tako su godine 635. Musli-

12 Muhamed Asad, Poruka Kur'ana, 364. Sarajevski prevoditelj sure 12,108 u Asadovu prijevodu na engleski ovako je formulirao: „Reci (Vjerovjesniče): Ovo je moj put, ja (vas sve) pozivam Allahu oslanjajući se na duhovni vid, dostupan razumu - ja i oni koji me slijede!“ Asad u komentaru upozorava da je ovdje upotrijebljena imenica besia koja označuje sposobnost razumijevanja temeljenu na svjesnom uvidu te stoga dostupna razumu." Ondje, 344.

13 Jane J. Smith, Faith, 167.

14 Tekst na bosanskom objavljen u Muslimova zbirka hadisa I, sažetak, Sarajevo, 2008., 11-12.

15 Podatak preuzet iz članka Jane J. Smith, Faith, 169. 
mani opsjedali Damask, kao važan grad Bizantskog Carstva. Prefekt grada bio je utjecajni član obitelji Mansur, koji nije volio bizantske gospodare i zato je muslimanima prilikom osvajanja predao ključeve Damaska. Bio je djed Ivana Damaščanina. Njegov sin Sargun, iako kršćanin, bio je neka vrsta ministra financija kalifa Mu'awija I. (660. - 680.). Sargunov sin Yahia dobio je kao kršćanski monah ime Ivan Damaščanin (oko 675. - 749.). Nakon što su muslimani osvojili Jeruzalem godine 638. dopustili su da monasi samostana Mar Sabe blizu Jeruzalema nastave svoju djelatnost. Njima se nakon godine 700. pridružio Ivan Damaščanin i nastavio monaški život pišući teološke spise. ${ }^{16}$ Kako je bizantski car državnom silom progonio teologe koji su zagovarali štovanje ikona, a Ivan je bio vatreni pobornik slika svetaca i proroka u kršćanskim crkvama i kultu, Ivan se osjećao sigurnim na području muslimanske vlasti u Svetoj zemlji. U svom djelu Izvor znanja, pisanom na grčkom, iznosi popis od 103 kršćanske hereze te među njih ubraja i islam. Sljedbenike islama naziva Jišmaelcima ili narodom Abrahamove žene Hagare te ističe da su nastali u vrijeme cara Heraklija tako što ih je okupio „lažni prorok Muhamed" nakon što je razgovarao s heretičkim monahom arijancem. ${ }^{17}$ Islam bi bio kristološka hereza zbog odbacivanja učenja da je Krist umro na križu i uvjerenja kršćana da Kristu raspetom i uskrsnulom mogu iskazivati božansko štovanje. On kao teološki obrazovani arapski kršćanin spominje doduše da su Jišmaelci prigodom Muhamedova nastupa bili idolopoklonici, ali ne vidi u tome propuste kršćanskih propovjednika. Pokazuje da zna za naslove nekih sura u Kur'anu i služi se arapskim tekstom sure druge, treće, četvrte i pete, ali se u polemici protiv islama oslanja umnogome na pučko praznovjerje kao da je to službeno kur'ansko učenje. Polemika protiv islama sastavljena je kao dijalog između kršćanina i zamišljenog muslimana kojemu autor stavlja u usta samo ono što kršćaninu odgovara. ${ }^{18}$ Unatoč tome jedan rumunjski pravoslavni teolog smatra da tekst Damaščanina može i danas biti poticaj na dijalog. ${ }^{19}$

16 Za život i djela Ivana Damaščanina usp. J. Pavić - T. Z. Tenšek, Patrologija, 304308. Usp. Robert Volk, Johannes von Damaskus, u: Lexicon für Theologie und Kirche 5, Freiburg, 2006., 895-899.

17 Grčki tekst i latinski prijevod Damaščaninove rasprave o islamu objavljen je $\mathrm{u}$ Patrologia graeca 94,763-778. Novije znanstveno izdanje Daniel J. Sahas, John of Damascus on Islam: The 'Heresy of the Ishmaelites', Brill, 1972.

18 John Ernest Merill, Of the Ttractate of John of Damaskus on Islam, The Muslim World, 41, (1951.) 2, 88-97. Ovaj je članak dostupan i na internetu, uvid 31. svibnja 2017.

19 Cajus Cutaru, A Great Father of the Church in Dialog with Islam: Saint John of Damascus, Teologia, (2014.) 4, 157-181. Teologia je časopis Pravoslavnog teo- 
Drugi srednjovjekovni teolog koji je u kršćanskim studentima teologije i filozofije izgrađivao stav prema islamu bio je Toma Akvinski (1225. - 1274.). U vremenu koje je prethodilo Akvinčevu kršćanski teolog Petar Časni (latinizirano ime Petrus Venerabilis, 1094. - 1156.) organizirao je prevođenje Kur'ana na latinski i nekih teoloških djela muslimanskih autora. To je znatno olakšalo kršćanskim teolozima proučavanje islama. ${ }^{20} \mathrm{U}$ djelu Suma protiv pogana, koje je nastalo između 1259. i 1265., iznosi filozofske temelje kršćanske vjere, a za dogmatske istine koje se temelje samo na Svetom pismu pokazuje da se ne protive ljudskom razumu. Na temelju proučavanja islama prema ondašnjim kršćanskim autorima smatra da muslimani vjeruju lakomisleno zato što Muhamed „nije pružio znakove nadnaravnog podrijetla“. ${ }^{21}$ Ubrzo nakon toga Akvinac je napisao Traktat o razlozima vjere protiv Saracena, posvećen jednom kršćanskom kantoru u Antiohiji koji živi među muslimanima i želio bi razumskim razlozima braniti svoju vjeru. ${ }^{22}$ Kršćani su u ono vrijeme Saracenima nazivali muslimane Arape i druge narode u zemljama muslimanske vlasti koji su prihvatili islam. Akvinac ovako sažima stav muslimana o kršćanstvu, kako mu je prenio kršćanin iz Antiohije:

„Saraceni se, kako kažeš, izruguju što mi Krista zovemo Sinom Božjim, a Bog nema žene. Također nas drže bezumnima što u Bogu ispovijedamo tri osobe, držeći da time priznajemo tri boga. Također se izruguju što kažemo da je Krist, Sin Božji, raspet za spasenje ljudskoga roda, jer ako je Bog svemoguć, mogao je ljudski rod spasiti bez trpljenja svoga Sina... Što se tiče zasluge, koja ovisi o slobodnoj volji, tvrdiš da i Saraceni i drugi narodi, zbog predznanja ili odredbe Božje, nameću ljudskim činima nužnost. Govore naime da čovjek ne može ni umrijeti ni sagriješiti doli kako je Bog čovjeku odredio, i da bilo koja osoba ima zapisan svoj ishod na čelu. U vezi s time moliš za ćudoredne i filozofske razloge koji su prihvatljivi za Saracene. Čini se naime da je uzalud navoditi mjerodavne riječi koje oni ne prihvaćaju. Prema tome, želeći udovoljiti tvoju molbu, koja, čini se, proizlazi iz pobožne želje da budeš spreman, prema apostolskom nauku, odgovoriti svakomu koji traži obrazloženje - izložit ću ti u vezi s

loškog fakulteta u Aradu, u Rumunjskoj.

20 Usp. Toma Akvinski, Razgovor s pravoslavnima i muslimanima. Protiv zabluda Grka o razlozima vjere (Protiv Saracena), s latinskog preveo, uvod i bilješke napisao Augustin Pavlović, KS, Zagreb, 1992., 92-105.

21 Toma Akvinski, Suma protiv pogana. Svezak prvi, preveo Augustin Pavlović, KS, Zagreb, 1993., 27-29.

22 Prijevod donosi Augustin Pavlović u Razgovor s pravoslavcima i muslimanima (bilj. 20), 225-253. 
prethodnim pitanjima neke lake razloge... Prema tome, namjera kršćanskog sugovornika glede članaka vjere treba smjerati ne da vjeru dokaže, nego da vjeru brani. Stoga i blaženi Petar ne kaže 'uvijek spremni za dokazivanje', nego 'za odgovor' tj. da se razumski pokaže kako ono što katolička vjera ispovijeda nije neistinito." 23

Iz ovog je navoda razvidno kako Akvinac ne traži od kršćanskog sugovornika da se odseli iz Antiohije, koja je većinski muslimanski grad, nego mu želi pomoći da svoju vjeru u susretima s muslimanima razumski obrazlaže. Također je razvidna i svijest o religijskom pluralizmu: vjera se ne može silom nametati ni matematički dokazati, ali može biti razumski prihvaćena i opravdana nakon što odrasla osoba slobodno prihvati vjeru zajednice u koju se uključila. Kod većine drugih kršćanskih teologa koji su pisali o islamu apologetika se pretvorila u izrugivanje i to je ostalo do sredine prošlog stoljeća.

Pioniri dijaloškog pristupa bili su rijetki kršćanski znanstvenici koji su neko vrijeme živjeli među muslimanima, naučili arapski jezik i proučavali njihovu kulturu. Među takve pionire na francuskom govornom području spadaju Louis Massignon (1883. - 1962.), Jean-Mohammed Abd-el-Jalil (1904. - 1979.), Louis Gardet (1905. 1986.), Georges C. Anawati (1906. - 1994.). ${ }^{24}$ Među katolicima novi pristup islamu prihvaćen je u Deklaraciji o odnosu Crkve prema nekršćanskim religijama na Drugom vatikanskom saboru. ${ }^{25}$

U vrijeme polemičke apologetike muslimanski su teolozi napadali kršćansku vjeru o Isusu u vidu isticanja ispravnosti islama. Čini se da je najstariji među njima Zaydi imam al-Qasim b. Ibrahim (umro godine 860.) sa svojim djelom Odgovor kršćanima. Opće uvjerenje muslimanskih teologa u prošlosti i danas je da je Isus dobivao pravu objavu, ali su je evanđelisti iskrivili u pisanim evanđeljima, kako su ona ušla u kanon prve Crkve. Unatoč tome islamski su apologeti uvjereni da obećanjem o „drugom Parakletu“ u Ivano-

23 Razgovor s pravoslavcima i muslimanima, str. 225-227.

24 Usp. Maurice Borrmans, Prophètes du dialogue islamo-chrétien: Louis Massignon, Jean-Mohammed Abd-el-Jalil, Louis Gardet, Georges C. Anawati, Éditions du Cerf, Paris, 2009. M. Borrmans bio je član Papinskog vijeća za međureligijski dijalog koje je priredilo Smjernice za dijalog između kršćana i muslimana (Glas Koncila, Zagreb, 1984.). Na hrvatski je prevedena njegova knjiga: Islam i kršćanstvo. Putovi dijaloga, Napredak, Sarajevo, 2010.

25 Usp. Disertaciju o dijalogu s muslimanima prema učenju Sabora i provedbenim smjernicama trojice papa, Tomislav Kovač, 'Crkva gleda s poštovanjem i muslimane' (NA 3). (Post)koncilski zaokret u odnosima Katoličke crkve prema islamu $i$ njegovi teološki izazovi, Vlastita naklada, Zagreb, 2016.; objavio sam recenziju ove knjige, Crkva u svijetu, 50 (2015.) 4, 668-671. 
vu evanđelju Isus najavljuje dolazak Muhameda. Prvi je to isticao Ali b. Rabban al-Tabari (umro oko 864.) u Knjizi o religiji i državi u kojoj je preveo oko 150 citata iz Biblije i tumačio ih kao najavu islama. ${ }^{26} \mathrm{~S}$. Balić ističe kako se Muhamed branio u odnosu na židovstvo i kršćanstvo pa se „teologija ni nakon njegove smrti ne može odreći apologetike“. Podsjeća da je sunitski islam u iznalaženju i dijeljenju pravde uveo pojam idžtihada tako da je „zahvaljujući raširenim anegdotama, pripovijestima i pjesmama apologetski duh zahvatio čak i pučku književnost“. Prema njemu, u strahu za vlastiti identitet u svijetu koji se mijenja apologetski islam najprije učvršćuje vjernost tradiciji. On vidi potrebu da muslimani misle svoju vjeru i organiziraju religijske strukture iz iskustva zapadnog pluralizma. ${ }^{27}$

Takav dijaloški stav opazio sam u prijevodu i komentaru Kur'ana koji je organizirao iranski filozof i teolog Seyyed Hossein Nasr u Sjedinjenim Državama. Njegovi suradnici su muslimanski intelektualci koji žive u Americi, ponosni na svoj religijski identitet i spremni na miran život sa sugrađanima drugih identiteta. ${ }^{28}$ Ovakva nakana posebno je razvidna iz petnaest preglednih tema namijenjenih čitateljima koji žele živjeti islam u zemljama zapadne demokracije. ${ }^{29}$ Prvu temu, „Kako čitati Kur’an“, obradila je Ingrid Mattson, koja je rođena i školovana u katoličkoj obitelji, ali je proučavanjem islama u Parizu 1986. prešla na islam i nametnula se svojim teološkim radovima o islamu kao slobodno odabranoj religiji. Ona predlaže da čitatelji uzmu u obzir kontekst u kojem je Kur'an objavljen i napisan, da se čuvaju pretpostavki i predrasuda, da uvažavaju povijesnu okolnost o vjernom prenošenju Gabrijelovih objava od strane Muhameda te da uvažavaju kontinuitet objave SZ, NZ i Kur'ana. Na kraju zaključuje: „Ugrađivati vrednote uljudnosti, međusobnog poštovanja i susjedstva u naše različite zajednice najbolji je način u sprečavanju da religijske razlike budu korištene za nanošenje nepravde jednih drugima, a to počinje i završava poštovanjem svetih Pisama te religijskog uvjerenja i prakse drugih." 30

Danas tolerantni kršćani i muslimani priznaju da vjeruju u istoga Boga koji se objavio po prorocima. To je emfatično pokazao

\footnotetext{
26 Pregled donosi David Thomas, Apologetics, Eciclopedia of the Qur'ān, Volme One, Leiden, 2001., 115-119.

27 Smail Balić, Apologetika - islamski, Leksikon temeljnih religijskih pojmova, 54 .

28 The Study Quran. A New Translation and Commentary, Seyyed Hossein Nasr, Editor-in-Chief,, Harper One, New York 2015, LIX + 1988 stranica i 11 geografskih karata. Usp. moju recenziju u Vrhbosnensia, 20 (2016.) 2, 476-488.

29 The Study Quran, 1587-1855.

30 Ingrid Mattson, How to read the Quran?, The Study Quran, 1600.
} 
Miroslav Volf, baptistički teolog rodom iz Osijeka koji djeluje u Americi, svojom knjigom Allah koju je 2011. objavio na engleskom, a izdavač hrvatskog prijevoda zamolio je pred objavljivanje profesora Adnana Silajdžića s Fakulteta islamskih nauka u Sarajevu da napiše svoj osvrt na Volfovo hrabro i ponizno razmišljanje. ${ }^{31}$ Kao pozitivno $\mathrm{u}$ Volfovu proučavanju on ističe to što osobno kontaktira s muslimanima te uočava kršćansku islamofobiju nakon terorističkog napada u New Yorku 11. studenog 2001. Hvali Volfovo „intertekstualno“ čitanje Novoga zavjeta i Kur'ana gdje su iz islama istaknuti Božji atributi života, znanja i moći kao analogija kršćanskom vjerovanju u Oca, Sina i Duha Svetoga. Prihvaća tezu da vjera u istoga Boga osposobljava kršćane i muslimane za miran život u pluralnom svijetu. Vjera u istoga Boga kršćaninu i muslimanu je poticaj da „svaki unosi ono što mu je Bog dao i time suradniku postaje znak i sredstvo Božjega djelovanja“. 32 Takva vjera može postati izvor najdubljih vrijednosti vjernika te potiče na ponašanje sukladno s odgovornošću pred Bogom i novim generacijama.

Bošnjački novinar Mirnes Kovač je po mandatu Međureligijskog vijeća za BiH priredio u travnju 2017. knjigu na engleskom One (Jedan), s citatima iz Biblije i Kur'ana o deset tema koje su zajedničke današnjim kršćanima i muslimanima. ${ }^{33}$ Suradnici u odabiru citata bili su mu Muhamed Fazlović, muslimanski teolog u Sarajevu koji je magisterij iz religija stekao na Gregoriani u Rimu, i Pavle Mijović, profesor filozofije na Katoličkom bogoslovnom fakultetu u Sarajevu. U predgovoru ističe: „U svetim knjigama vjernici mogu naći pouke i upute koje mogu izravno utjecati na njihove živote: kršćani doživljavaju Božju prisutnost po Isusu kao snagu da pokazuju uljudnost, ljubav i milosrde, dok muslimani te ideale nalaze $\mathrm{u}$ riječima Kur'ana koje su ispunjene u životu Proroka Muhameda. Široki ideal vjerovanja usmjeren je na težnju za nedokučivom uporabom onoga što imamo ovdje i sada u svijetu koji nas okružuje. Ljudi nalaze snagu u vjeri a to je nešto što svaki treba u našem ubrzanom svijetu punom sukoba. Ipak, ta prvotna bitna vjera, koju redovni ljudi nastoje živjeti što je bolje moguće, bila je nažalost često zloupotrebljavana i primjenjivana kao sredstvo mržnje, kao gorivo za zločin i apsurdno ubijanje najdivnijeg Božjeg stvorenja - čovje-

31 Usp. Adnan Silajadžić, Pogovor: Nema istinskog kršćansko-muslimanskog dijaloga bez zrele i odgovorne vjere, u: Miroslav Volf, Allah. Kršćanski odgovor, Ex Libris, Rijeka, 2015., 320-342.

32 Adnan Silajdžić, Pogovor, (bilj. 31), 340.

33 Mirnes Kovač, One. Words of God from the Holy Books of both Islam and Christianity, Sarajevo, Međureligijsko vijeće za Bosnu i Hercegovinu 2017. 
ka. Upravo radi toga odlučili smo u knjizi Jedan običnim ljudima učiniti dostupnijima poruke iz Biblije i Kur'ana."34 Citati iz Biblije preuzimani su iz New American Bible, a citati iz Kur'ana iz Asadova prijevoda i komentara na engleskom godine 1980., koji je 2004. preveden i na bosanski. Deset zajedničkih vrijednosti koje su važne za vjernike u sekularnoj državi s pluralističkim društvom su: vjera $\mathrm{u}$ jednoga Boga, mogućnost i potreba mira, socijalna pravda, ljubav prema Bogu i bližnjima, obitelj i susjedstvo, svetost života, samilost, opraštanje, pomirenje, pomaganje drugima, nada. Pretpostavljam da je razlog citiranja na engleskom osjetljivost prijevoda. Naime, pitanje je čiji prijevod kod starješina i vjernika uživa recepciju i na koji od triju službenih jezika u BiH. Nadam se da će svećenici, imami i vjeroučitelji svojim vjernicima u molitvenim nastupima i konfesionalnom školskom vjeronauku svojim učenicima približavati te teme.

\section{OD MUSLIMANA U JUGOISTOČNOJ EUROPI DO EUROPSKOG ISLAMA}

Povijesno, prvi muslimani koji su se našli na tlu današnje Slovenije bili su Bošnjaci u sastavu austrougarske vojske u Prvom svjetskom ratu. Slovenija je 1918. uključena u novu državu Južnih Slavena, a od pedesetih godina prošloga stoljeća počeli su se u nju doseljavati muslimanski radnici iz Bosne, Kosova i Sandžaka, što znači s područja bivše Osmanske Carevine. ${ }^{35}$ Opća politika turske okupacijske vlasti u Albaniji, na Kosovu, u Srbiji te Bosni nije bila nasilno islamiziranje, nego zadržavanje domaćih stanovnika na području muslimanske vlasti uz stanovito jamstvo sigurnosti (millet), ali su kršćani morali plaćati vjerski porez zvan džizija i nisu smjeli obnašati državne službe u zemlji. To je, zbog više od 400 godina takve vlasti, dovelo do postupne islamizacije tako da danas muslimani čine većinu stanovnika u Albaniji, na Kosovu te u BiH. Za razliku od muslimana u Britaniji, Francuskoj, Njemačkoj i nordijskim zemljama svi su oni potomci domaćih starosjedilaca, ne doseljenika koji bi došli s turskom vlašću. ${ }^{36}$ Nakon što su se odlukom europskih država u Berlinu 1878. Turci morali povući iz Bosne, a poslije i iz drugih krajeva Balkana, ovdašnji muslimani trebali su sa svojim političkim i vjerskim vođama odlučiti hoće li se

$34 \quad$ Mirnes Kovač, One (bilj. 30), Foreword, bez oznake stranice.

35 Usp. Christian Moe, Slovenia, u: Yearbook of Muslims in Europe. Volume 2, Editor-in-Chief Jurgen S. Nielsen, Boston, 2010., 473-480.

36 Usp. poglavlje „Islamizacija Bosne“, u: Noel Malcolm, Bosna. Kratka povijest, Sarajevo, 2011., 121-148. 
odseliti u Tursku, na područje muslimanske vlasti, ili će se uklopiti u novu sekularnu državu. Golema većina je ostala, s vremenom se izborila za svoja religijska i etnička prava te sada stoje pred zadaćom biti lojalnim građanima sekularne države i čuvati svoj vjerski identitet, što uspješno ostvaruju. ${ }^{37}$ Bošnjački muslimani ističu da su Europljani, ne doseljenici, što ih ne čini manje muslimanima od Arapa, Pakistanaca, stanovnika Indonezije i drugih. Stalo im je da u sekularnim državama sačuvaju svoj islamski identitet. ${ }^{38}$ Takvi su očito i muslimani Slovenije, koji su većinom potomci doseljenih Bošnjaka. Tu otvorenost za Europu bošnjački muslimani pokazuju mirnim uključivanjem svoje dijaspore u zemlje Europe i Amerike te u Australiju. Pastoralnu brigu o vlastitoj dijaspori koordinira Rijaset IZ u BiH. ${ }^{39}$

Poznato je da muslimanski doseljenici u Zapadnoj Europi desetljećima dobivaju imame i vjeroučitelje iz zemalja iz kojih su došli te da turski imami u Austriji i Njemačkoj ne govore jezik zemlje u kojoj poučavaju svoje vjernike. Posebno je osjetljivo pitanje vjeronauka u državnim školama za djecu muslimanskih roditelja, jer država ima svoje odredbe o školskom programu pa i vjeronauku, uvažavajući opravdane zahtjeve roditelja. Francuske vlasti određuju da imami koji dolaze iz arapskih zemalja (bivših francuskih kolonija) odslušaju niz predavanja o zemlji u kojoj žive njihovi vjernici kako bi im pomagali $u$ bezbolnom uklapanju u radnu sredinu i čuvanju muslimanskog identiteta. U nekim zemljama Europe sve više se zagovara osnivanje studija islama za buduće imame u zemljama gdje će služiti.

Dobro informirani kršćanski intelektualci pišu kako muslimani nisu opasnost za zemlje zapadne demokracije niti za kršćane u tim

37 Usp. Ina Mredjanova, Rediscovering the Umma. Muslims in the Balkans between Nationalism and Transnationalism, New York, 2013. Ovu sam knjigu recenzirao: Muslimani u zemljama Jugoistočne Europe između vlastite nacije i univerzalnosti svoje vjere, Vrhbosensia, 18 (2014.) 1, 267-273. Spremnost muslimana u ovim zemljama na dijalog sa sugrađanima drugih vjera autorica je obradila i u knjizi: Ina Merdjanova - Patrice Brodeur, Religija kao pokretač razgovora. Međureligijski dijalog za izgradnju mira na Balkanu, Sarajevo, 2014. (na engleskom tiskana 2009,).

38 Usp. Besjeda reisu-ul-uleme Huseina ef. Kavazovića na Univerzitetu u Pečuhu: Mi smo muslimani i Evropljani, Preporod 7, svibanj 2016., 28-31. Enes Karić, Čekajući Evropu. Eseji, Sarajevo, 2015. Fikret Karčić, The Other - Bosnian Muslims. A. Bosnian Experience, CNS, Sarajevo, 2015.

39 U monografiji Islamska zajednica u Bosni i Hercegovini, Sarajevo, 2013., 692-734, iznesen je pregled bošnjačkih islamskih zajednica u Zapadnoj Europi, Australiji i Sjevernoj Americi. 
zemljama. ${ }^{40}$ Kršćanski vjerski poglavari, prihvaćajući ljudska prava muslimana, nastoje svoje vjernike informirati o islamu te preko vlastitih organizacija pomagati muslimanima u dotičnim zemljama $\mathrm{u}$ bezbolnom integriranju, koje ne bi smjelo biti asimilacija. Tako su katolički biskupi Njemačke 23. rujna 2003. izdali radni dokument u obliku knjige Kršćani i muslimani u Njemačkoj. ${ }^{41}$ U predgovoru podsjećaju da su godine 1983. izdali sličan dokument, ali je iskustvo susreta s muslimanima u zemlji dovelo do naglog porasta znanstvene literature o islamu te $\mathrm{u}$ isto vrijeme do potrebe zbližavanja radi zajedničkog življenja u državi koja poštuje religijske vrijednosti i $\mathrm{u}$ isto vrijeme ostaje konfesionalno neutralna. U prvom dijelu knjiga predstavlja različite muslimanske zajednice u Njemačkoj (suniti i šiiti, aleviti, mistici, zatim arapski, iranski, turski muslimani). U drugom poglavlju predstavljen je islam kao vjera i način života, uspoređene su osnovne istine kršćanstva i islama. U trećem poglavlju predstavljen je islam u njemačkom društvu, uključujući potrebu izgradnje džamija te pouke o islamu u katoličkom vjeronauku. U drugom dijelu su odgovori na konkretna pitanja: domovi za stare, obrezanje, ukapanje, brak, slavljenje blagdana, marama za žene, vjeronauk za muslimane u državnim školama.

U gradiću sjeverne Francuske Saint-Étienne-du-Rouvray dva su nasilnika u ranim jutarnjim satima 26. srpnja 2016. provalila u jednu crkvu, za taoce uzeli skupinu prisutnih vjernika te uz obrednu okrutnost ubili svećenika Jacquesa Hamela, starog 86 godina. Jedna vjernica uspjela se izvući iz crkve te pozvati policajce, koji su u okršaju likvidirali ubojice. Istraga je poslije pokazala da su ubojice pripadali ekstremističkoj islamskoj organizaciji koja, između ostaloga, ubija i nevine muslimane kako bi kaznila zapadne predstavnike vlasti. Mjesto ubojstva ubrzo je pohodio francuski predsjednik Hollande. Žalostan događaj bio je povod za novi val sumnjičenja muslimana kao nesposobnih ili nespremnih da se uklope u sekularnu državu zapadne demokracije. Jedan je svećenik u 15.43 istoga dana preko interneta poručio: „Molimo za žrtve i ubojice. Ne podliježimo osveti. Oprosti im, ne znaju što čine!" Francuski biskupi uputili su svojim vjernicima i društvenoj javnosti 14. listopada poruku

40 Usp. John L. Esposito, Islamska prijetnja mit ili stvarnost?, Živinice, 2001. Na bosanski preveo Ahmet Alibašić, recenzent dr. Enes Karić. Ovaj kršćanski proučavatelj islama ne zatvara oči pred terorističkim činima muslimanskih ekstremista, ali ih ne izjednačuje s islamom kao religijom. Usp. njegovu knjigu Islam and Politics, Syracuse University Press, New York, ${ }^{4} 1998$.

41 Sekretariat der Deutschen Bishofskonferenz, Christen und Muslime in Deutschland (Arbeitshilfen 172), Bonn, 2003., 277 stanica. Popis najvažnijih knjiga o islamu na njemačkom, namijenjenih općoj vrsti čitatelja, str. 370-277. 
naslovljenu: „U svijetu koji se mijenja ponovno pronaći smisao za političko“. ${ }^{42}$ Polaze od društvene napetosti koja vlada među francuskim građanima i vjeruju da društvene mreže mogu unijeti kvalitetu u javnu raspravu o društvu u kojem će svoje mjesto nalaziti mladi i stari različitog porijekla i socijalnog položaja. Svjesni da nije moguće stvoriti apsolutnu sigurnost, ali jest moguće štititi temeljne slobode, smatraju da je nezaposlenost velika nepravda te ističu da mnogim francuskim suvremenicima republikanske vrijednosti slobode, jednakosti i bratstva zvuče kao riječi bez sadržaja. Pitaju se zašto se neki mladi ne integriraju u francusko društvo, nego vide smisao svog života u ratovanju u Siriji i Iraku. Spočitavaju politici da je izgubila osjećaj za smisao te postala upravljačka (gestionnaire), a time je degradiran projekt Europe. Predlažu relegitimaciju javne riječi, ponovno promišljanje laičnosti na kojoj se temelji francuska država i poklanjanje više prostora religiji u društvu: „Laičnost države je pravni okvir koji treba dopustiti svima, vjernicima svih religija i onima koji ne vjeruju, da žive zajedno. Ne smije nadilaziti svoj objektiv želeći laičnost učiniti socijalnim projektom kojemu bi cilj bio religijska neutralizacija toga društva, izgoneći religijsko iz javne sfere u čisto privatnu domenu gdje bi religija ostala skrivena. Takvo poimanje štetno je za društvo. Ne uvažava osobe i donosi frustracije koje jačaju komunitarizam." 43

Jedna od muslimanskih organizacija u Francuskoj je Teološko vijeće muslimana Francuske, sa sjedištem u Parizu. Ono je izdalo otvoreno pismo francuskim biskupima, 1. studenog 2016., u kojem se sa zahvalnošću osvrće na poruku biskupa. ${ }^{44} \mathrm{U}$ uvodu ističu: „Knjižica koju ste upravo objavili pod naslovom 'U svijetu koji se mijenja ponovno pronaći osjećaj za političko’ izraziti je poziv na zajedničko življenje kakvog nije bilo posljednjih godina. Zahvaljujemo vam u ime Boga, njegovih stvorenja, vjernika i onih koji ne vjeruju u Francuskoj koja nam je zajedničko dobro. Svečani ton koji ste upotrijebili dobro odgovara težini situacije i ozračju napetosti koje prevladava u zemlji i u današnjem svijetu. “45 Izražavaju ogorčenost

42 Dans un monde qui change retrouver le sens du politique. Le Conseil permanent de la Conference des évêques de France aux habitatants de notre pays, tekst objavljen u katoličkom dnevniku La Croix 17. 10. 2016. i u posebnoj knjižici; dostupan na internetu obuhvaća 16 stranica.

43 Dans un monde qui change retrouver le sens du politique (bilj. 42), n. 9.

44 Lettre du Conseil Théologique musulmans de France à la Conference des évêques de France, objavljeno u časopisu Oumma i na: https://oumma.com/lettre-duconseil-theologique-musulmans-de-france-a-la-conference-des-eveques-defrance/; (25. svibnja 2017).

45 Lettre du Conseil Thèologique musulmans de France (bilj. 44), uvod. 
nad odbacivanjem drugih i nasiljima koja se događaju u svijetu, a to stvara nepovjerenje i sumnjičenja bližnjih. Zatim nastavljaju: „Francuska, pet puta žrtva terorističkih atentata nečuvene nasilnosti, s više od 250 mrtvih u manje od dvije godine, i stotine ranjenih, nije iznimka u tom oceanu nesreća. " ${ }^{46} \mathrm{U}$ nastavku izriču pohvalu biskupima za uravnoteženu reakciju prigodom ubojstva svećenika Hamela kojom su poslali jasnu poruku svijetu i ubojicama: „Masovno sudjelovanje francuskih muslimana na različitim misama koje su posvuda organizirane $u$ Francuskoj $u$ spomen na toga prelata, mučenika odurnog divljaštva koje ubija bezobzirno, bilo je prvi korak koji treba poduprijeti i nastaviti. Razbijmo konačno ograde koje nas razdvajaju! Naše su dogme svakako različite, ali ima toliko točaka koje nas povezuju da bi bilo dovoljno neke primjenjivati kako bismo definitivno pobijedili suprotnosti koje je često ljudska povijest postavila među nas. Za to bismo trebali veličati milosrđe, mir, bratstvo, uzdizati ih, živjeti ih, na njih neprestano pozivati.“ Obećaju suradnju muslimana u suprotstavljanju ideologiji mržnje i prihvaćanju kompleksnosti ondje gdje bi neki željeli nametnuti simplicizam. Laičnost Francuske znači da nijedan građanin nije iznad zakona Republike i da ne smije biti maltretiran radi svoga uvjerenja. „Znadete bolje nego itko da je došla okončati ocean nepravdi i stoljeća rata koji su zavili u crno ili okaljali našu zemlju i njezinu povijest. Nikada joj nije bio poziv borba protiv religija niti propisivanje kako će se Francuzi oblačiti." 47

Glavni tajnik Religions for Peace u New Yorku dr. William Vendley razaslao je 8. lipnja 2017. engleski tekst poruke dr. Mustafe Cerića u povodu terorističkih napada u Manchesteru 27. svibnja i Londonu 3. lipnja 2017. Reis emeritus obraća se muslimanima Europe priznajući kako se osjeća zbunjenim u pokušaju objašnjenja onoga što se događa u njegovoj vjerskoj zajednici i oko nje. Zatim ističe: „Znam da ima onih koji će ustvrditi kako smatram da su krvavi napadi protiv nevinih civila u Manchesteru i Londonu važniji od napada u Palestini, Kabulu, Mosulu, Sa'anu i Misrati. Nisu važniji, ali svakako jesu opasniji za muslimane u Europi, a većina njih pobjegli su iz zemalja s muslimanskom većinom da potraže mir i sigurnost za svoju djecu u Europi. Sada je taj mir i sigurnost koji su dosada doživljavali u velikoj opasnosti. Nakon napada u Manchesteru i Londonu, a prije toga u Parizu, Berlinu i Zürichu velik oblak nesigurnosti nadvio se nad muslimane Europe. Europski muslimani

46 Lettre du Conseil Théologique musulmans de France (bilj. 44), elektronski tekst.

47 Lettre du Conseil Théologique musulmans de France (bilj. 44), elektronski tekst. 
trebaju biti toga svjesni. Stoga europski muslimani trebaju glasno i jasno osuditi nasilje 'u ime Allaha', ali trebaju poduzimati i konkretne korake protiv zloporabe islama u svakom pogledu. Europski muslimani trebaju imati ujedinjen, jasan i nedvosmislen glas u borbi protiv nasilja činjenog tobože $u$ ime Allaha. To više nije stvar dobre volje pojedinaca i skupina koji djeluju u međuvjerskom dijalogu, nego je egzistencijalno pitanje islama i muslimana u Europi." 48

Zbog terorističkih napada muslimanskih ekstremista porasla je među kršćanima u zemljama zapadne demokracije islamofobija ili zlobno širenje straha od muslimana kao opasnosti. O tom socijalnom i vjerskom fenomenu postoje vjerodostojna istraživanja. ${ }^{49}$ Ayhan Kaya, profesor u Istanbulu, koji objavljuje sociološke radove na njemačkom i engleskom, oblikuje stavove islamofobije u osam načela:

1. Islam se gleda kao monolitni blok, statičan i nespreman na promjene

2. Islam nema zajedničkih vrijednosti s drugim kulturama, ne prima utjecaje niti se trudi da utječe

3. Islam je inferiorniji od Zapada, barbarski, iracionalan, primitivan i pun seksualnih predrasuda

4. Islam je nasilan, agresivan, podupire terorizam i zauzet je za sukob civilizacija

5. Islam je politička ideologija i upotrebljava se za političke probitke

6. Islamska kritika Zapada odbacuje se

7. Hostilnost prema islamu izlika je za diskriminaciju muslimana i isključivanje iz glavnih tokova društva

8. Protumuslimanska hostilnost smatra se normalnom. ${ }^{50}$

On u zaključku ističe da su muslimanski doseljenici šezdesetih i sedamdesetih godina gledani s poštovanjem, kao dobrodošli radnici. Nezadovoljstvo i diskriminacija počeli su socijalno-ekonomskim i političkim promjenama u tim zemljama te radikalizacijom nekih potomaka tih useljenika nakon terorističkih napada Al-Qaide. To je donijelo postrožene postupke za useljavanje. Tako izolirani muslimani Europe „počeli su nalaziti utočište u potpori određenih zajed-

48 Uvid 9. lipnja 2017. na internetskoj stranici Religions for Peace.

49 Usp. Ahmet Alibašić i Muhamed Jusić (prir.), Islamofobija-pojam, pojava, odgovor, Sarajevo, 2015. Knjiga je prevedena s engleskog, a sastoji se od 47 priloga nastalih od 1998. do 2012. Objavio sam o njoj recenziju u Vrhbosnensia, 19 (2015.) 1, 256-261.

50 Ayhan Kaya, Islamophobia, u: Jocelyne Cesari (ed.), The Oxford Handbook of European Islam, Oxford, 2015, 739-769. Na str. 752 donosi tablicu s postotcima odgovora na neka osjetljiva pitanja o muslimanima u sedam europskih država. 
nica na temelju emocija (communities of sentiments), kao što su religijska, etnička, kulturna i drugarska zajednica. Takve osjećajne zajednice nude imigrantima i njihovoj djeci utočište koje ih štiti od nesigurnosti, neizvjesnosti, nejasnoće, siromaštva, nezaposlenosti i isključenja. U tom smislu, religioznost je jedna od najpouzdanijih taktika za migrante kako bi se održali u postojećim strukturalnim problemima." 51

Među naslovima popisa literature na četiri stranice navodi i „Smjernice edukatorima o suprotstavljanju netoleranciji i diskriminaciji protiv muslimana. Obrađivanje islamofobije kroz naobrazbu i odgoj" iz godine 2011. Dao ih je izraditi UNESCO, a OSCE ih preporučuje svima koji djeluju u obrazovno-odgojnom sustavu europskih zemalja. ${ }^{52}$ Nakon uvoda dokument od 70 stranica obrađuje pitanja: očitovanje netolerancije i diskriminacije muslimana, metodološka načela i pristupi, strategije u školama, mogući izazovi, pomagala i sredstva informiranja. Uz 22 stručnjaka na dokumentu su radile 4 vladine organizacije i 9 nevladinih. Dokument sažima uobičajene predrasude prema muslimanima: svi su isti, svi su motivirani religijom, oni su totalno drugačiji, kulturno i moralno su niži, prijetnja su za opću sigurnost, nisu spremni za suradnju. Odgovor na te stereotipe kroz obrazovno-odgojni sustav trebao bi biti:

- U islamu je oduvijek bilo, kao što je i danas, razlika i unutarnjih rasprava.

- Ljudi s muslimanskom pozadinom imaju niz drugačijih stavova prema religijskom uvjerenju i praksi u odnosu na ljude rođene u drugim tradicijama.

- Ljudi koji pripadaju različitim religijskim ili kulturnim zajednicama - uključujući muslimane, kršćane, Židove i druge - mogu imati i imaju pozitivan utjecaj jedni na druge te često rade i žive zajedno u bliskoj suradnji i partnerstvu.

- Tijekom stoljećâ islamske kulture i civilizacije pridonijele su značajno znanosti i tehnologiji, umjetnosti i arhitekturi, pravu, etici i filozofiji. 53

Jedan od muslimana koji žive u zemljama s većinskim kršćanskim stanovništvom je i Tariq Ramadan, koji zagovara prilagodbu

51 Ayhan Kaya, Islamophobia, 765.

52 Guidelines for Educators on Countering Intolerance and Discrimination against Muslims. Adressing Islamophobia through Education, internetski uvid 8. lipnja 2017.

53 Usp. Guidelines for Educators on Countering Intolerance and Discriminatio against Muslims (bilj. 52), 26-27. 
europskim sekularnim strukturama i kulturi, uz čuvanje muslimanskog vjerničkog identiteta, ali i očekuje dovoljan prostor slobode za muslimane. ${ }^{54}$ Katolički biskupi i teolozi u europskim zemljama nastoje kod vlastitih vjernika otkloniti nepotreban strah od muslimana kao sugrađana u istoj zemlji. Protestantski teolog u Nizozemskoj Bert de Ruiter drži studentima u svojoj zemlji predavanja o nadvladavanju straha od islama i predlaže zajedničko življenje bez međusobnog sumnjičenja (naslov njegove knjige je Sharing Lives). ${ }^{55}$

Kako je Republika Slovenija u sastavu EU, samim time su i muslimani u Sloveniji europski muslimani. Međutim, kako bi slobodno prakticirali svoj religiozni identitet, potrebno im je razumijevanje i potpora građanske i vjerničke većine. Tko ima iskustvo pripadati religijskoj ili etničkoj manjini, zna da smo svi skloni biti arogantni ondje gdje smo većina te da smo kao manjine sigurni tek kada nam većinski sugrađani svojim mentalitetom i ponašanjem priznaju naše potrebe.

\section{ZAKLJUČAK}

Na temelju mojeg iskustva življenja u Sarajevu kao gradu s apsolutnom većinom muslimana i na osnovi nastojanja da provodim smjernice Drugoga vatikanskog sabora o dijalogu s današnjim muslimanima u mojoj zemlji i drugdje po svijetu, moj odgovor na pitanje iz naslova je pozitivan. Da, moguće je razumski braniti kršćanstvo i islam nakon što kao odrasli vjernici prihvatimo pripadnost svojoj vjerničkoj zajednici, čitamo vlastite svete knjige te se od imama, svećenika i vjeroučitelja dadnemo poučiti u vlastitoj vjeri. To traži da njegujemo zajedničke vrijednosti kao građani sekularne države u pluralističkom društvu i da poštujemo razlike. To pretpostavlja da svoju vjeru sve dublje upoznajemo i da se dajemo informirati o vjeri drugih, da jedni drugima dopustimo predstavljati se onako kako sami sebe vidimo. U katoličkoj teologiji religijskog dijaloga prebačen je naglasak s vjerske istine kao takve na ljude koji zadržavaju svoje ljudsko dostojanstvo i temeljna prava i kad su drugačiji po vjeri, kulturi i političkim uvjerenjima.

54 Usp. Tarik Ramadan, Evro-američki muslimani i budućnost islama, Sarajevo, 2007.; Tariq Ramadan, Moje uvjerenje, Sarajevo, 2011.

55 Bert de Ruiter, Sharing Lives. Overcoming Our Fear of Islam, OM Books, Linz, 2010. Evo naslova poglavlja u njegovoj knjizi: 1. Budućnost islama u Europi; 2. Suočavanje sa strahom od muslimana; 3. Pomoć kršćanima u nadvladavanju islamofobije; 4. Zajednički živjeti: studentski tečaj za kršćane; 5. Testiranje i vrednovanje tečaja. 


\section{HOW CAN CHRISTIANS AND MUSLIMS DEFEND THEIR OWN FAITH WITHOUT RESORTING TO MUTUAL MOCKERY?}

\section{Summary}

This paper was prepared as one of presentations at the Interreligious Conference in Ljubljana, 25 October 2017. It consists of three parts: Adult believers, after they have acquired sufficient knowledge of belief in divine revelation, can rationally explain it; In time of dialogue we study shared values and respect differences without mocking; From Muslims in Southeast Europe to European Islam. The author concludes: Based on my experience of living in Sarajevo as a city with an absolute Muslim majority, while striving to implement the guidelines of Vatican II in dialogue with present-day Muslims in my country and elsewhere in the world, my response to the question in the title of this presentation is positive. Yes, it is possible to defend rationally Christianity and Islam after we, as adult believers, have accepted our membership in a faith community, read our sacred books and received sufficient instruction from imams, priests and religious teachers in our own faith. This requires that we cherish the shared values as citizens in secular and plural societies and respect mutual differences. This also supposes that we do study our own faith and are open to being informed about the faith of others. We should allow each other to present ourselves as we see ourselves. In the Catholic theology of interreligious dialogue the accent has been moved from religious truth per se to human persons maintaining their human dignity and fundamental rights even if they remain different in faith, culture and political conviction. dialogue

Key words: Muslims, Christians, rational evidence, respect, 